\title{
STRATEGI KOMUNIKASI PENUTUR ANAK DALAM INTERAKSI DENGAN BERBAGAI MITRATUTUR PADA LINGKUNGAN MASYARAKAT DIGLOSIK
}

\author{
Dyah Werdiningsih \\ Fakultas Keguruan dan Ilmu Pendidikan Universitas Islam Malang \\ e-mail: dyahwerdi@yahoo.co.id
}

\begin{abstract}
This study aims to describe characteristics of child speakers' communication strategies in their interaction with a variety of interlocutors in a diglossic society. This study was a longitudinal study involving subjects aged $2-5$ years. The data were collected through observations, recording with an electronic recorder, and field note cards. The data were analyzed using the performance analysis technique. The findings show that characteristics of child speakers' communication strategies in their interaction with a variety of interlocutors in a diglossic society appear in the types and type variations, causes, and functions of the use in the process of naturally acquiring the pragmatic competence.
\end{abstract}

Keywords: communication strategies, child speakers, interlocutors, diglossia, pragmatic competence

\section{PENDAHULUAN}

Dalam proses pemerolehan kompetensi pragmatik terdapat faktor penting yang perlu diperhatikan, yaitu usaha anak untuk memperoleh bentukbentuk tuturan yang berterima untuk menyatakan maksud dan mengkomunikasikannya ketika berinteraksi dengan mitra tutur. Berkenaan dengan hal ini, para pakar (Corder, 1980; Tarrone, 1980; dan Ellis, 1986) menyatakan bahwa dalam berkomunikasi dengan bahasa yang sedang dipelajari seseorang berusaha menggunakan berbagai strategi untuk menguasai bentuk-bentuk tuturan yang diperlukan untuk menyatakan maksud dan mencapai keberhasilan tujuan komunikasi yang diinginkan.

Kajian strategi komunikasi merupakan hal penting dalam proses pemerolehan bahasa. Strategi komunikasi digunakan pembelajar bahasa sebagai usaha untuk menjebatani kesenjangan antara pengetahuan bahasanya dan pengetahuan bahasa mitra tuturnya dalam proses komunikasi yang di- hadapinya (Tarone, 1983). Lebih lanjut, Corder (1983) berpendapat bahwa strategi komunikasi adalah teknik yang sistematis dan digunakan pembelajar untuk mengekspresikan idenya ketika mengalami kesulitan karena penguasaan bahasa yang belum sempurna.

Komunikasi dalam proses pemerolehan bahasa merupakan media bagi pembelajar untuk melatih dan mengembangkan pengetahuan bahasanya. Dalam berkomunikasi seseorang berusaha menggunakan berbagai bentuk kebahasaan yang telah dikuasainya untuk menyatakan maksud dan pikirannya kepada orang lain. Dalam usaha untuk dapat berkomunikasi tersebut terdapat hal penting yang perlu dikaji, yaitu bagaimana cara anak berkomunikasi dalam bahasa yang sedang diperlajari-nya itu. Penyampaian pesan dalam komunikasi oleh anak yang belum menguasai bahasa target secara sempurna ini dapat berlangsung dalam berbagai cara. Hal ini bergantung pada situasi dan kondisi saat komunikasi berlang- 
sung dan berbagai faktor lain yang berpengaruh (Corder, 1983).

Berdasarkan pengamatan, dalam suatu proses komunikasi anak dapat berhasil dengan baik menyatakan maksudnya kepada orang lain. Akan tetapi, pada saat yang lain masih mengalami kesulitan untuk mengekspresikan maksudnya dengan menggunakan bahasa yang sedang dipelajarinya itu (Oxford, 1990). Kesulitan ini membuat mereka seringkali tidak dapat menyatakan maksudnya melalui ujaran-ujaran yang tepat. Bahkan, mereka justru menghindari komunikasi tertentu karena khawatir akan terjadi kesalahan apabila mereka melanjutkan komunikasi.

Untuk mengatasi problem tersebut, anak mencari dan menggunakan strategi tertentu sebagai jalan keluar sehingga maksudnya dapat dikomunikasikan. Penggunaan strategi komunikasi ini dipengaruhi oleh beberapa faktor, antara lain adalah tingkat penguasaan bahasa, sumber-sumber masalah kesulitan dalam pengungkapan sebuah tuturan, kepribadian pembelajar, dan situasi atau lingkungan anak. Pengaruh beberapa faktor tersebut terhadap pemilihan dan penggunaan strategi komunikasi telah dibuktikan oleh Tarone (1977), Ellis (1986), dan Bialystok (1983).

Sebagai penutur yang belum menguasai bahasa secara sempurna, proses pemerolehan kompetensi pragmatik anak-anak didukung oleh penggunaan strategi pemerolehan bahasa yang meliputi strategi komunikasi tertentu. Berdasarkan pengkategorian kompetensi pragmatik yang dikemukakan oleh Bachman (1990), pemerolehan kompetensi pragmatik anak ini mencakup aspek kompetensi ilokusi dan kompetensi sosiolinguistik. Kompetensi ilokusi tergambar pada kemampuan anak untuk mengemukakan maksud tertentu kepada mitra tuturnya, yaitu untuk menjelaskan fakta, menanyakan fakta, menyatakan nasihat, menyatakan terima kasih, menyatakan permohonan, menyatakan ma'af, menyatakan penolakan, menyatakan pendapat, dan memberi nasihat, dan lain-lain. Adapun kompetensi sosiolinguistik tampak pada kepekaan anak menggunakan bentukbentuk tuturan yang sesuai dengan konteks. Dengan demikian, strategi pemerolehan kompetensi pragmatik anak tampak pada cara-cara yang digunakan anak untuk menguasai bentuk-bentuk tuturan yang digunakan untuk menyatakan maksud tertentu kepada mitra tuturnya sesuai dengan konteks penggunaannya.

Berdasarkan gagasan tersebut, pemerolehan kompetensi pragmatik anak terealisasi pada tindak tutur dalam komunikasi, yakni terwujud pada kompetensi ilokusi. Kompetensi ilokusi tersebut tampak pada tuturan anak dengan ciri-ciri tertentu. Aspek-aspek pragmatik dalam tindak tutur inilah yang merupakan bentuk nyata dari penggunaan bahasa dalam berbagai peristiwa komunikasi. Pengkajian strategi pemerolehan kompetensi pragmatik dalam tindak tutur ini juga didasarkan pada pandangan bahwa unit komunikasi bahasa bukan berupa simbol, kata, atau kalimat, tetapi lebih merupakan pemroduksian simbol, kata, atau kalimat yang terealisasi dalam tindak tutur (Mey, 1993:110; Schiffrin, 1994:54; dan Duranti, 2000:45). Pertimbangan lain perlunya pengkajian strategi pemerolehan kompetensi pragmatik ini adalah adanya fakta bahwa penutur anak yang dijadikan subjek penelitian ini telah mempunyai kemampuan untuk memproduksi tuturan secara lengkap (Foster, 1990). Dalam hasil penelitian terdahulu, yang antara lain dilakukan oleh Ghozali (1998) dan Arifin (2000), dikemukakan bahwa penutur anak telah mampu menggunakan tuturan secara bervariasi dan bermakna. Dengan 
adanya fakta tersebut peneliti terdorong untuk melakukan penelitian ini dengan menggunakan subjek penutur anak dalam pemerolehan kompetensi pragmatik berbahasa Indonesia.

Sejalan dengan uraian tersebut, penelitian ini dimaksudkan untuk mengkaji tentang strategi pemerolehan kompetensi pragmatik, yang difokuskan pada penggunaan strategi komunikasi pada penutur anak. Kajian ini ditekankan pada pembahasan tentang tipe-tipe, faktor penyebab, dan fungsi penggunaan strategi komunikasi dalam pemerolehan kompetensi pragmatik penutur anak.

Penelitian ini difokuskan pada pengkajian tentang bagaimana proses akulturasi pemerolehan kompetensi pragmatik berbahasa Indonesia (BI) anak prasekolah dalam lingkungan keluarga Etnik Jawa di perkotaan yang terepresentasi pada penggunaan strategi komunikasi dalam pemerolehan kompetensi pragmatik berbahasa Indonesia (berBI) penutur anak. Secara rinci, tujuan penelitian ini adalah mengkaji strategi komunikasi dalam pemerolehan kompetensi pragmatik ber-BI penutur anak, yakni (1) mengkaji strategi penggunaan bentuk nonverbal dalam pemerolehan kompetensi pragmatik ber-BI penutur anak, yang meliputi penggunaan isyarat dan gerakan, penggunaan gerakan, penggunaan gambar, dan penggunaan lagu dan (2) mengkaji strategi penggunaan bentuk verbal dalam pemerolehan kompetensi pragmatik ber-BI penutur anak, yang meliputi (a) strategi penggunaan bentuk tuturan, yaitu pengalihan kode tuturan, pemaparan tuturan, dan penciptaan kata kreatif, dan (b) strategi pengungkapan isi tuturan, yaitu penjelasan maksud tuturan, pengalihan topik tuturan, dan pemutusan pesan.

Dari sejumlah penelitian terdahulu, terdapat beberapa persamaan dan perbedaan yang dapat dikemukakan baik dari segi substansi, metodologi, maupun teori. Perbedaan penelitian ini dibandingkan dengan penelitian yang telah ada adalah (1) penelitian ini dilakukan dalam konteks penggunaan bahasa oleh penutur anak yang terjadi secara alamiah, (2) penelitian ini difokuskan pada kajian terhadap fungsi penggunaan strategi komunikasi dalam proses pemerolehan kompetensi pragmatik, (3) penelitian ini menggunakan subjek dwibahasawan Jawa-Indonesia yang tinggal di lingkungan keluarga etnik Jawa di perkotaan, dan (4) penelitian ini menggunakan pendekatan kualitatif dengan desain longuitudinal dan penjaring data berupa pengamatan tuturan anak yang disertai dengan pedoman pengamatan, alat perekaman elektronik, dan alat pencatatan data lapangan. Beberapa hasil penelitian terdahulu yang relevan selengkapnya terdapat dalam lampiran.

\section{METODE}

Untuk mencapai tujuan penelitian, dalam penelitian ini digunakan pendekatan kualitatif. Penggunaan pendekatan kualitatif ini didasarkan pada beberapa alasan sebagai berikut.

Pertama, objek penelitian yang dikaji dalam penelitian ini adalah fenomena penggunaan bahasa anak usia $2-5$ tahun yang tinggal di lingkungan masyarakat diglosik dalam interaksi dengan berbagai mitra tutur dalam konteks alamiah. Kealamiahan itu tampak pada data penelitian yang berupa tuturan dalam komunikasi verbal anak-anak dalam lingkungan masyarakat diglosik yang diperoleh melalui kegiatan komunikasi dalam kehidupan mereka seharihari.

Kedua, dalam hal ini peneliti sebagai instrumen kunci. Oleh karena, fenomena penggunaan bahasa penutur anak di lingkungan masyarakat diglosik ini dipahami, diidentifikasi, dianalisis, 
dan ditafsirkan oleh peneliti sendiri. Interaksi yang mendalam antara peneliti dan tuturan serta data pendukung yang terkait dengan fenomena kebahasaan yang menjadi objek kajian dalam penelitian ini merupakan kunci untuk memahami fenomena penggunaan strategi komunikasi penutur anak di lingkungan masyarakat diglosik.

Ketiga, tujuan penelitian ini adalah mengkaji fenomena penggunaan strategi komunikasi penutur anak di lingkungan masyarakat diglosik di kota Malang. Untuk mencapai tujuan penelitian tersebut, jalan penelitian dilakukan secara induktif. Cara ini ditempuh berdasarkan dua pertimbangan, yakni data dan fakta-fakta dalam penelitian ini tidak digunakan untuk membuktikan atau menolak hipotesis yang sudah ditentukan lebih dahulu, tetapi peneliti membuat abstraksi dari hal-hal khusus berdasarkan data kemudian menyusun sebagai suatu simpulan-simpulan sementara hingga pada akhirnya diperoleh simpulan akhir. Dengan demikian, peneliti mengembangkan dan menyusun teori tentang karakteristik strategi komunikasi penutur anak yang berakar dari data.

Ancangan teori yang digunakan dalam penelitian ini adalah teori strategi komunikasi dan kompetensi komunikatif. Teori tersebut dimanfaatkan untuk mengkaji, melacak, dan menemukan penggunaan strategi komunikasi, yaitu meliputi bentuk, karakteristik, faktor penentu, fungsi, dan peran strategi komunikasi dalam mencapai kompetensi komunikatif penutur anak di lingkungan masyrakat diglosik.

Data penelitian ini terdiri atas tuturan anak dalam berinteraksi di lingkungan masyarakat diglosik dengan berbagai mitra tutur dan catatan lapangan tentang konteks komunikasi yang diperoleh dari hasil pengamatan peneliti di lapangan.
Subjek penelitian ini adalah penutur anak usia $2-5$ tahun yang tinggal di lingkungan masyarakat tutur yang menggunakan dua bahasa dengan fungsi berbeda. Dari hasil perekaman tuturan dan pengamatan terhadap perilaku berbahasa penutur anak dapat diidentifikasi bentuk, faktor penentu, fungsi, dan efek penggunaan strategi komunikasi penutur anak di lingkungan masyarakat diglosik.

Subjek penelitian adalah delapan anak prasekolah dwibahasawan JawaIndonenesia, usia 2, 3, 4, dan 5 tahun masing-masing 2 orang sehingga sejumlah 8 orang. Penentuan jumlah subjek didasarkan pada pendapat Walfram (dalam Rofi'uddin, 1990) bahwa dalam penelitian psikolinguistik subjek penelitian dapat terdiri atas lima sampai sepuluh subjek penelitian. Penetapan subjek penelitian ini didasarkan pada asas kecukupan data yang diperlukan dalam penelitian ini. Penentuan delapan subjek ini dilakukan dengan alasan bahwa dengan enam subjek tersebut diprediksi telah diperoleh data yang cukup memadahi untuk menjawab permasalahan penelitian ini. Namun, jika ternyata perolehan data belum memenuhi target sebagaimana yang diharapkan maka dilakukan penambahan subjek hingga memenuhi kecukupan data.

Kedelapan subjek yang digunakan dalam penelitian ini memiliki karakteristik sebagai berikut (1) berasal dari lingkungan keluarga yang tinggal di lingkungan masyarakat diglosik, (2) sejak kecil telah dikenalkan pada dua bahasa, dengan kata lain anak sejak awal telah dididik menjadi dwibahasawan Jawa-Indonesia, dan (3) bertempat tinggal di lingkungan masyarakat dwibahasa di kota Malang.

Dalam penelitian ini peneliti berlaku sebagai instrumen kunci. Oleh karena, data dalam penelitian ini berupa perilaku manusia yang hanya dapat di- 
pahami melalui interaksi antara peneliti dengan subjek dan faktor-faktor yang berperan dalam kegiatan berkomunikasi subjek. Adapun instrumen tambahan yang digunakan adalah pedoman pengamatan dan alat bantu pengamatan, yaitu perekam elektronik (tape recorder) serta alat pencatatan lapangan.

Pedoman pengamatan dalam penelitian ini disusun sebagai ramburambu mengenai apa yang harus diamati dalam melakukan pengamatan lapangan. Pedoman pengamatan disusun untuk mengumpulkan data dalam bentuk tuturan verbal yang diujarkan subjek beserta konteks tuturan yang menyertai dalam interaksi anak dwibahasawan Jawa-Indonesia dengan mitra tuturnya. Dalam kegiatan pengamatan lapangan dilakukan perekaman data, yaitu tuturan anak dengan berbagai mitra tutur. Perekaman data dilakukan dengan menggunakan alat perekam elektronik (tape recorder), baik dilakukan secara sembunyi-sembunyi maupun sepengetahuan subjek. Hal ini dilakukan untuk menjaga kealamiahan data yang diperoleh dari semua subjek. Selama kegiatan pengamatan berlangsung dilakukan pencatatan data lapangan.

Teknik pengumpulan data yang digunakan adalah teknik pengamatan. Teknik pengamatan dilakukan baik dengan partisipasi maupun nonpartisipasi. Pengamatan difokuskan pada kegiatan penutur anak di lingkungan masyarakat diglosik dalam melakukan interaksi verbal dengan berbagai mitra tutur. Teknik pengamatan dilengkapi dengan pencatatan lapangan dan perekaman. Perekaman data dilakukan untuk memperoleh data yang berupa tuturan bahasa anak dalam berinteraksi di lingkungan masyrakat diglosik di kota Malang. Data ini diperlukan untuk menjawab masalah penelitian, yaitu untuk mengkaji penggunaan strategi komunikasi penutur anak dengan ber- bagai mitra tutur.

Untuk mencapai tujuan penelitian ini, berbagai data pendukung penelitian ini dianalisis berdasarkan teknik analisis performansi. Teknik analisis ini didasarkan pada gagasan LarsenFreeman dan Long (1991) bahwa tipe analisis data dalam penelitian pemerolehan bahasa meliputi analisis kontrastif, analisis kesalahan, analisis performansi, dan analisis wacana. Dengan teknik analisis performansi, analisis data dilakukan berdasarkan perilaku berbahasa dan tuturan aktual yang diperformansikan subjek sebagai wujud dari kemampuan berbahasa dan cara penguasaannya. Dengan teknik analisis ini peneliti dapat menjelaskan suatu fenomena bahasa secara mendalam dengan memanfaatkan fakta kebahasaan tertentu yang menjadi sasaran penelitian. Selain itu, peneliti memiliki keleluasaan untuk melakukan interpretasi terhadap rekaman percakapan yang diperoleh dari subjek.

Sejalan dengan teknik analisis ini, alur kegiatan analisis terdiri atas beberapa langkah yang terjadi secara bersamaan, yaitu seleksi data, reduksi data, penyajian data, dan penarikan simpulan. Seleksi data dilakukan terhadap hasil perekaman tuturan subjek penelitian yang diperoleh dari pengamatan. Data tuturan verbal hasil rekaman penggunaan bahasa subjek ditranskripsikan ke dalam bentuk tulisan dengan diberi tambahan keterangan tentang situasi yang melatarbelakangi tuturan tersebut kemudian diklasifikasikan sesuai dengan kategori data, yaitu tuturan pada kegiatan interaksi. Pengumpulan data dilakukan berdasarkan prinsip keaslian, kebenaran, kelengkapan, dan kejenuhan data.

Dalam tahap reduksi data dilakukan proses pemilihan, pemusatan perhatian, penyederhanaan, dan pengidentifikasian data yang muncul dari rekaman dan catatan lapangan. Reduksi 
data dilakukan dengan cara memilih dan memilah data yang relevan dengan tujuan penelitian. Selanjutnya, dilakukan simplifikasi data, yaitu data yang terpilih disederhanakan sejalan dengan tujuan penelitian. Pengidentifikasian data dilakukan berdasarkan kategori data dalam strategi belajar dan strategi komunikasi dengan tipe-tipe tertentu. Reduksi data ini dilakukan secara terus-menerus selama penelitian berlangsung.

Penyajian data merupakan proses pengkodean data, pengklasifikasian data, dan pemaparan data penelitian. Pengkodean data dilakukan untuk memudahkan kegiatan analisis data. Kode yang digunakan berupa simbol-simbol singkat sesuai dengan karakteristik data. Pengkodean data dilakukan berdasarkan ciri subjek, kategori data, dan urutan data. Pengklasifikasian data dilakukan sesuai dengan masalah penelitian, yaitu memilah data dalam beberapa kategori. Pemaparan data dilakukan berdasarkan satuan-satuan tuturan yang menggambarkan penggunaan strategi belajar dan strategi komunikasi anak yang dilengkapi dengan keterangan mengenai konteks, yang meliputi: peristiwa tutur, topik, mitra tutur, tujuan, latar, dan situasi tutur yang diperoleh dari pencatatan lapangan. Pembahasan penggunaan strategi komunikasi penutur anak diarahkan pada kajian dalam pemerolehan kompetensi pragmatik yang dijabarkan dalam aspek-aspek pragmatik tindak tutur model Van Ek (1990).

Penyimpulan data dilakukan berdasarkan hasil analisis terhadap strategi komunikasi penutur anak yang ditekankan pada bentuk, faktor penentu penggunaan, dan fungsi penggunaannya dalam pemerolehan kompetensi pragmatik. Hasil analisis data tersebut diabstraksikan menjadi simpulan sementara. Untuk memperoleh kesahihan simpulan dilakukan pengecekan keabsahan temuan penelitian melalui pen- gecekan data dan teoretis dengan cara mengkonfirmasi hasil analisis data dan teori yang terkait yang telah diuraikan dalam kajian teori. Hal ini dilakukan untuk mendapatkan pengukuhan atas kredibilitas temuan penelitian.

\section{HASIL DAN PEMBAHASAN}

Berdasarkan hasil analisis data ditemukan penggunaan strategi komunikasi penutur anak memiliki karakteristik yang tampak pada (1) tipe dan variasi tipe, (2) faktor penyebab, dan (3) fungsi penggunaannya dalam pemerolehan kompetensi pragmatik.

\section{Tipe dan Variasi Tipe Strategi Komuni- kasi Penutur anak}

Berdasarkan hasil analisis data strategi komunikasi penutur anak digunakan dalam tujuh tipe dengan enam belas variasi tipe strategi komunikasi. Berdasarkan paparan tentang penggunaan strategi komunikasi penutur anak dalam tabel tersebut diperoleh gambaran bahwa (1) anak usia 2 tahun menggunakan dua tipe strategi yang masing-masing direalisasikan dalam dua variasi tipe strategi dan digunakan untuk menyatakan tiga aspek pragmatik, (2) anak usia 3 tahun menggunakan lima tipe strategi yang masing-masing direalisasikan dalam tujuh variasi tipe strategi dan digunakan untuk mengatasi kendala komunikasi dalam delapan aspek pragmatik, (3) anak usia 4 tahun menggunakan lima tipe strategi masingmasing direalisasikan dalam sepuluh variasi tipe strategi dan digunakan untuk menyatakan sepuluh aspek pragmatik, dan (4) anak usia 5 tahun menggunakan enam tipe strategi direalisasikan dalam dua belas variasi tipe strategi dan digunakan untuk menyatakan dua belas aspek pragmatik. Paparan tersebut memperlihatkan bahwa pada tiap jenjang usia anak terjadi perkembangan penggunaan tipe dan variasi tipe strate- 
gi komunikasi dan aspek pragmatik yang dikuasai oleh anak. Semakin tinggi usia anak semakin variatif tipe strategi komunikasi yang digunakan dan aspek pragmatik yang dikuasai dalam komunikasi.

Strategi penggunaan bentuk nonverbal digunakan anak usia prasekolah secara berbeda-beda sejalan dengan perkembangan usia dan tingkat penguasaan bahasa mereka. Strategi ini digunakan anak dalam empat tipe, yaitu penggunaan isyarat dan gerakan, penggunaan gerakan, penggunaan gambar, dan penggunaan lagu. Strategi penggunaan bentuk verbal oleh anak usia prasekolah merefleksikan upaya anak untuk memanfaatkan bentuk-bentuk tuturan yang telah dikuasainya untuk berkomunikasi. Strategi penggunaan bentuk verbal ini digunakan anak usia prasekolah dalam dua tipe, yaitu (1) strategi penggunaan bentuk tuturan dan (2) strategi penggunaan isi tuturan. Strategi penggunaan bentuk tuturan digunakan anak usia prasekolah dalam tiga variasi tipe, yaitu pengalihan kode tuturan, pemaparan tuturan, dan penciptaan kata kreatif. Strategi pengungkapan isi tuturan digunakan anak dalam tiga variasi tipe, yakni penajaman maksud tuturan, pengalihan topik tuturan, dan pemutusan pesan.

Berdasarkan temuan penelitian ini klasifikasi penggunaan strategi komunikasi penutur anak berdasarkan pengklasifikasian para pakar dipaparkan dalam tabel 1 dan 2.

Tabel 1. Klasifikasi Penggunaan Strategi Komunikasi Penutur Anak Bentuk NonVerbal

\begin{tabular}{|c|c|c|}
\hline $\begin{array}{c}\text { Tipe Strategi } \\
\text { Komunikasi } \\
\text { Penutur anak }\end{array}$ & $\begin{array}{c}\text { Kategori } \\
\text { Strategi Komunikasi }\end{array}$ & $\begin{array}{c}\text { Klasifikasi Tipe } \\
\text { Strategi Komunikasi } \\
\text { Para Pakar }\end{array}$ \\
\hline Penggunaan Isyarat & $\begin{array}{l}\text { - Achievement or } \\
\text { Compensatory Strategies } \\
\text { (Canale \& Swain, } \\
\text { 1983), }\end{array}$ & $\begin{array}{l}\text { - Mime (Tarrone, 1983) } \\
\text { - Using Mime or Gesture } \\
\text { (Oxford, 1990) } \\
\text { - Non-verbal (Haastrup dan }\end{array}$ \\
\hline Penggunaan Gerakan & $\begin{array}{l}\text { - Borrowing Strategies } \\
\text { (Tarrone, 1983), }\end{array}$ & $\begin{array}{l}\text { Philipson, 1983) } \\
\text { - Non-linguistics Means }\end{array}$ \\
\hline Penggunaan Gambar & $\begin{array}{l}\text { - Non-verbal Strategies } \\
\text { (Bialystok, 1983; } \\
\text { Haastrup dan } \\
\text { Philipson (1983), }\end{array}$ & (Canale \& Swain, 1983) \\
\hline Penggunaan Lagu & $\begin{array}{l}\text { - Compensation Strategies } \\
\text { (Oxford, 1990) }\end{array}$ & \\
\hline
\end{tabular}


Tabel 2. Klasifikasi Penggunaan Strategi Komunikasi Penutur Anak Bentuk Verbal

\begin{tabular}{|c|c|c|}
\hline $\begin{array}{l}\text { Tipe Strategi } \\
\text { Komunikasi } \\
\text { Penutur anak } \\
\end{array}$ & $\begin{array}{c}\text { Kategori } \\
\text { Strategi Komunikasi }\end{array}$ & $\begin{array}{c}\text { Klasifikasi Tipe } \\
\text { Strategi Komunikasi } \\
\text { Para Pakar } \\
\end{array}$ \\
\hline $\begin{array}{l}\text { Pengalihan Kode } \\
\text { Tuturan }\end{array}$ & $\begin{array}{l}\text { - Achievement or } \\
\text { Compensatory Strategies } \\
\text { (Canale \& Swain, } \\
\text { 1983), } \\
\text { - Borrowing Strategies } \\
\text { (Tarrone, 1983), } \\
\text { - L1-Based Strategies } \\
\text { Bialystok (1983), } \\
\text { - Compensation Strategies } \\
\text { (Oxford, 1990) }\end{array}$ & $\begin{array}{l}\text { - Code Switchingto L1 or L3 } \\
\text { (Canale \& Swain, 1983) } \\
\text { - Language Switch (Tarrone, } \\
\text { 1983; Blum-Kulka dan } \\
\text { Levenston, 1983) } \\
\text { - Switching to the Mother } \\
\text { Tongue (Oxford, 1990) }\end{array}$ \\
\hline Pemaparan Tuturan & 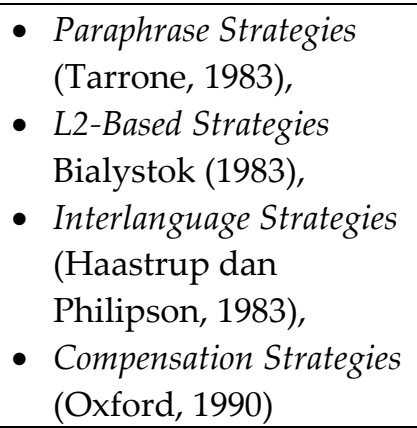 & $\begin{array}{l}\text { - Circumlocution (Tarrone, } \\
\text { 1983; Canale \& Swain, } \\
\text { 1983) } \\
\text { - Paraphrase } \\
\text { (Haastrup dan Philipson, } \\
\text { 1983) } \\
\text { - Using a circumlocution or } \\
\text { synonym (Oxford, 1990) }\end{array}$ \\
\hline $\begin{array}{l}\text { Penciptaan Kata } \\
\text { Kreatif }\end{array}$ & 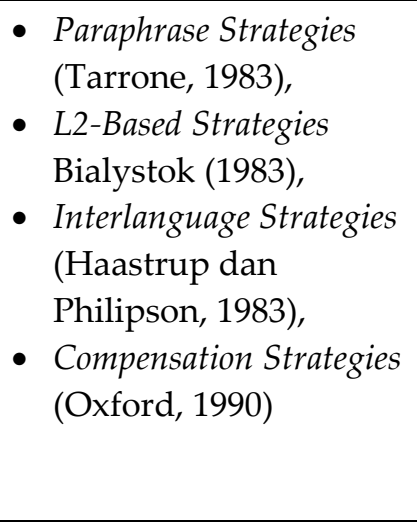 & $\begin{array}{l}\text { - Word Coinage (Tarrone, } \\
\text { 1983; Haastrup dan } \\
\text { Philipson, 1983; Blum- } \\
\text { Kulka dan Levenston, } \\
\text { 1983; Canale \& Swain, } \\
\text { 1983) } \\
\text { - Coining Words (Oxford, } \\
\text { 1990) } \\
\text { - Word Creation (Clark, } \\
\text { 1983; Clark dan Berman, } \\
\text { 1987) }\end{array}$ \\
\hline $\begin{array}{l}\text { Penajaman Maksud } \\
\text { Tuturan }\end{array}$ & $\begin{array}{l}\text { - Interactional Strategies } \\
\text { (Canale \& Swain, } \\
\text { 1983), } \\
\text { - Borrowing Strategies } \\
\text { (Tarrone, 1983), } \\
\text { - Cooperative Strategies } \\
\text { Bialystok (1983) dan }\end{array}$ & $\begin{array}{l}\text { - Appeals for Help (Canale } \\
\text { \& Swain, 1983), } \\
\text { - Appeal for Assistance } \\
\text { (Tarrone, 1983) } \\
\text { - Getting Help (Oxford, } \\
\text { 1990) } \\
\text { - Cooperative Strategies } \\
\end{array}$ \\
\hline
\end{tabular}




\begin{tabular}{|c|c|c|}
\hline & $\begin{array}{l}\text { Haastrup dan } \\
\text { Philipson (1983), } \\
\text { - Compensation Strategies } \\
\text { (Oxford, 1990) }\end{array}$ & $\begin{array}{l}\text { (Haastrup dan Philipson, } \\
\text { 1983) } \\
\text { - Appeal to Authority } \\
\text { (Blum-Kulka dan } \\
\text { Levenston, 1983) }\end{array}$ \\
\hline $\begin{array}{l}\text { Pengalihan Topik } \\
\text { Tuturan }\end{array}$ & $\begin{array}{l}\text { - Avoidance (Tarrone, } \\
\text { 1983, Canale \& Swain, } \\
\text { 1983), } \\
\text { - Compensation Strategies } \\
\text { (Oxford, 1990) }\end{array}$ & $\begin{array}{l}\text { - Topik Avoidance (Tarrone, } \\
\text { 1983) } \\
\text { - Selecting the Topic } \\
\text { (Oxford, 1990) } \\
\text { - Change of Topic (Blum- } \\
\text { Kulka dan Levenston, } \\
\text { 1983) }\end{array}$ \\
\hline Pemutusan Pesan & $\begin{array}{l}\text { - Avoidance (Tarrone, } \\
\text { 1983, Canale \& Swain, } \\
\text { 1983), } \\
\text { - Compensation Strategies } \\
\text { (Oxford, 1990) }\end{array}$ & $\begin{array}{l}\text { - Massage Abandonment } \\
\text { (Tarrone, 1983) } \\
\text { - Avoiding Communication } \\
\text { Partially or Totally } \\
\text { (Oxford, 1990) }\end{array}$ \\
\hline
\end{tabular}

Strategi komunikasi penutur anak dapat dikelompokkan dalam dua kategori, yaitu strategi penggunaan bentuk nonverbal dan strategi penggunaan bentuk verbal. Yang tergolong strategi penggunaan bentuk nonverbal adalah (1) penggunaan isyarat dan gerakan, (2) penggunaan gerakan, (3) penggunaan gambar, dan (4) penggunaan lagu. Adapun strategi penggunaan bentuk verbal terdiri atas dua kategori, yaitu (1) strategi penggunaan bentuk tuturan yang terdiri atas strategi pengalihan kode tuturan, pemaparan tuturan, dan penciptaan kata kreatif, dan (2) strategi pengungkapan isi tuturan yang terdiri atas strategi penajaman maksud tuturan, pengalihan topik, dan pemutusan pesan.

\section{Faktor Penyebab Penggunaan Strategi Komunikasi Penutur anak}

Penggunaan strategi komunikasi pada anak usia prasekolah ini disebabkan oleh adanya berbagai faktor, yaitu tingkat perkembangan usia, tingkat penguasaan bahasa, sumber problema komunikasi, kepribadian pembelajar, tujuan komunikasi, dan situasi belajar. Peran berbagai faktor tersebut diuraikan sebagai berikut. Pengaruh faktor perkembangan usia dalam proses pemerolehan kompentensi pragmatik anak usia prasekolah ditunjukkan denganadanya kesejajaran antara perkembangan usia dengan perkembangan strategi komunikasi yang digunakan anak. Hal ini ditunjukkan dengan adanya perbedaan tipe dan variasi tipe strategi komunikasi yang digunakan anak pada setiap jenjang usia (lihat tabel 5.3). Sebagaimana pada perkembangan strategi belajar, perkembangan usia anak berpengaruh pada perkembangan strategi komunikasi yang digunakan anak usia prasekolah dalam pemerolehan kompetensi pragmatik. Dengan demikian, temuan penelitian ini juga mendukung temuan Burt, Dulay, dan Krashen (1982) tentang adanya pengaruh perkembangan usia terhadap proses pemerolehan bahasa.

Tingkat penguasaan bahasa anak berperan penting dalam pemilihan dan penggunaan tipe dan variasi tipe strate- 
gi komunikasi tertentu. Salah satu aspek yang mendukung tingkat penguasaan bahasa anak adalah lama waktu belajar bahasa. Pada anak usia prasekolah lama waktu belajar bahasa diketahui berdasarkan perbedaan waktu mulainya belajar bahasa, yakni sesuai dengan usia anak pada masing-masing jenjang. Dari temuan penelitian ini diperoleh gambaran bahwa tingkat penguasaan bahasa yang berbeda mengakibatkan perbedaan tipe dan variasi tipe strategi komunikasi yang digunakan anak pada tiap jenjang usia, meskipun terdapat beberapa persamaan. Sebagaimana pada perkembangan strategi belajar, fakta ini menggambarkan bahwa perkembangan strategi komunikasi anak usia prasekolah seiring dengan tingkat penguasaan bahasa. Dengan demikian, temuan ini juga mendukung pernyataan Hacth (1983) dan Ellis (1986) bahwa lama waktu belajar bahasa dapat mendukung tingkat penguasaan bahasa, terutama pada proses penguasaan kompetensi komunikasi.

Pengaruh faktor sumber problema komunikasi terhadap penggunaan strategi komunikasi anak usia prasekolah terbukti pada penggunaan strategi yang didasarkan pada bahasa bahasa lain yang dikuasai anak (BJ) dan strategi yang didasarkan pada bahasa target (BI). Penggunaan strategi komunikasi yang didasarkan pada BJ ditunjukkan dengan penggunaan strategi pengalihan kode tuturan pada tuturan anak usia 2, 3, 4, dan 5 tahun. Anak usia 2 tahun melakukan pengalihan kode tuturan dalam bentuk penggunaan kata/ frase BJ, sedangkan anak usia 3, 4, dan 5 tahun melakukan pengalihan kode tuturan dalam bentuk penggunan kata/ frase BJ dan penggunaan kalimat BJ. Penggunaan pengalihan kode tuturan pada anak usia prasekolah dalam penelitian ini dilakukan anak tidak selalu karena penguasaan BJ lebih baik daripada BI, tetapi karena anak memanfaatkan kedwibahasaannya dengan menggunakan kedua bahasa yang dikuasainya secara bergantian. Temuan ini menunjukkan bahwa anak usia prasekolah memiliki kemampuan untuk memanfaatkan kedwibahasaannya untuk mencapai tujuan komunikasi. Penggunaan strategi komunikasi yang berda-sarkan pada BI ditunjukkan dengan penggunaan strategi pemaparan tuturan dan penciptaan kata kreatif. Strategi komunikasi berdasarkan bahasa target tersebut digunakan anak usia prasekolah pada usia 3, 4, dan 5 tahun. Strategi ini belum digunakan pada anak usia 2 tahun karena untuk menggunakannya memerlukan penguasaan bahasa yang cukup. Hal itu sejalan dengan pernyataan Ellis (1986) bahwa pada umumnya penutur dengan penguasaan bahasa target yang terbatas lebih suka menggunakan strategi berdasarkan B1 atau bahasa yang lebih dikuasainya. Adapun penutur dengan penguasaan bahasa yang cukup baik biasanya menggunakan strategi-strategi berdasarkan bahasa target (Bialystok, 1986). Karena sejak dini dapat menggunakan BJ dan BI, untuk mengatasi problem komunikasi yang dihadapi anak usia prasekolah dapat memilih menggunakan strategi komunikasi berdasarkan BJ atau BI.

Kepribadian anak memberikan pengaruh terhadap penggunaan strategi komunikasi pada penggunaan strategi permintaan bantuan yang dilakukan secara langsung kepada mitra tuturnya. Pada anak usia 2 hingga 5 tahun tidak ditemukan penggunaan permintaan bantuan secara tidak langsung. Dengan demikian, temuan ini mendukung pernyataan Tarone (1983) dan Ellis (1986) bahwa pembelajar dengan kepribadian yang terbuka akan cenderung memilih cara meminta bantuan secara langsung 
sedangkan pembelajar dengan kepribadian tertutup cenderung memilih cara tidak langsung dengan alasan untuk menyelamatkan muka.

Tujuan komunikasi memberikan pengaruh pada penggunaan strategi komunikasi anak usia prasekolah yang ditunjukkan dengan semua strategi komunikasi yang digunakan dalam pemerolehan kompetensi pragmatik. Semua tipe dan variasi tipe strategi komunikasi yang digunakan anak berorientasi pada ketercapaian tujuan komunikasi. Dengan strategi komunikasi yang digunakan, meskipun anak tidak dapat menyatakan maksud dalam bentuk tuturan yang benar tetapi tujuan komunikasi dapat tercapai. Hal itu sejalan dengan pernyataan Chiat (2001) bahwa dengan menggunakan strategi komunikasi tertentu meskipun anak mengalami keterbatasan berbahasa, tidak selalu mereka mengalami kesulitan pragmatik. Demikian juga pernyataan Keller dan Rech (1998:315) bahwa keterbatasan anak terhadap aspek linguistik tidak membatasi perilaku mereka untuk berkomunikasi.

Situasi belajar dalam lingkungan bahasa yang alamiah memberikan pengaruh terhadapkeleluasaan anak dalam menggunakan strategi komunikasi. Hal ini ditunjukkan dengan tidak adanya kendala bagi anak untuk memanfaatkan berbagai strategi komunikasi sesuai dengan kebutuhannya. Namun, bukan berarti semua anak usia prasekolah mampu menggunakan semua strategi komunikasi yang ada. Kemampuan anak dalam mengguna-kan strategi komunikasi bergantung pada kompetensi strateginya pada masing-masing jenjang usia.

Dalam situasi belajar yang terjadi secara alami anak dapat menggunakan berbagai strategi untuk dapat menggunakan bentuk-bentuk tuturan yang diperlukan untuk berinteraksi dengan mitra tuturnya. Dengan proses penggunaan bahasa secara alami ini anak dapat mencapai keberhasilan dalam menguasai bahasa target (Bruner, 1983). Sejalan dengan hal itu, Vigotsky (1986) berpendapat bahwa spoken language should develop in natural way through children's interaction with the people of the culture in which they are growing up.

Temuan penelitian tentang faktor-faktor penyebab penggunaan strategi komunikasi yang telah dipaparkan tersebut menggambarkan bahwa proses pemerolehan kompetensi pragmatik anak melibatkan faktor internal dan faktor lingkungan bahasanya. Dengan demikian, temuan ini mendukung pandangan teori interaktif dalam proses pemerolehan bahasa (Clark dan Clark, 1977 dan Ellis, 1986 dan 1995).

Penggunaan strategi komunikasi anak usia prasekolah ini menunjukkan adanya proses interaktif pada pemerolehan kompetensi pragmatik ber-BI anak, yakni adanya keterlibatan faktor kematangan perangkat bawaan bahasa anak dan masukan bahasa yang dipajankan kepada anak. Faktor kematangan perangkat bawaan bahasa anak ini merupakan piranti yang berperan penting sebagai pemroses internal dalam struktur mental anak, yakni sebagai penyun-ting dan penyaring masukanmasukan bahasa yang berasal dari lingkungan bahasanya dan sebagai pengorganisasi yang berperan dalam menginternalisasikan masukan-masukan bahasa yang terdapat dalam lingkungan sekitarnya menjadi sistem kaidah yang dikuasai anak. Adapun faktor masukan bahasa yang dipajankan kepada anak mempe-ngaruhi proses pemerolehan kompetensi pragmatik anak terkait dengan pemanfaatan bentuk-bentuk tuturan yang dipajankan kepada anak untuk mengungkapkan maksud- 
maksud tertentu kepada mitra tuturnya dalam praktik berkomunikasi.

Dari penelitian ini diperoleh gambaran adanya karakteristik perkembangan kompetensi pragmatik anak usia prasekolah yang ditunjukkan dengan penggunaan bentuk-bentuk tuturan yang sejalan dengan tahapan perkembangan bahasa anak. Menurut Steinberg (1982), perkembangan awal ujaran terjadi dalam tiga tahap, yaitu: (1) tahap penamaan dan holoprastis, (2) tahap telegrafis, dan (3) tahap transformasional dan morfemis. Adapun menurut Schaerlaekens (1977), tahap-tahap perkembangan bahasa anak dibagi ke dalam empat periode, yaitu: (1) periode prelingual (0-1 tahun); (2) periode lingual dini (1-2,5 tahun), yang meliputi periode satu kata, periode dua kata, dan periode lebih dari dua kata; (3) periode diferensiasi (usia 2,5-5 tahun); dan (4) periode perkembangan bahasa sesudah usia 5 tahun.

Sesuai dengan tahap perkembangan bahasa anak, pada usia 2 tahun anak banyak menggunakan tuturan dalam kalimat satu kata. Kalimat satu kata ini digunakan anak untuk menyatakan berbagaimaksud, mislanyamenyatakan perintah, penolakan, pertanyaan, permintaan, dan lain-lain. Penginterpretasian tuturan anak ini bergantung pada konteks penggunaan-nya. Untuk dapat memahami maksud tuturan anak dengan baik, mitra tutur perlu mengetahui apa yang sedang dilakukan anak saat kata tersebut diujarkan. Intonasi juga dapat mempermudah interpretasi apakah anak bertanya, memberi tahu, atau memerintah. Sebagai contoh, pada usia 2 tahun anak menyatakan tuturan Pisang kepada ibunya, sesuai dengan konteks penggunaannya tuturan tersebut digunakan anak untuk menyatakan permintaan bahwa anak minta buah pisang kepada ibunya. Menurut Neil et al. (1970), anak mempunyai kalimat-kalimat dalam pikirannya, tetapi karena keterbatasan ingatan dan perhatiannya sehingga mereka hanya dapat mengujarkan satu kata saja. Adapun menurut Ingram (1971), anak telah mempunyai cukup banyak ide yang dapat dirangkaikan menjadi satu kalimat, tetapi tidak dapat menuangkannya dalam bentuk kalimat yang lengkap karena belum mempunyai kemampuan linguistik yang memadai.

Sejalan dengan tahap perkembangan bahasanya, pada usia 2-3 tahun anak menyatakan berbagai maksud dengan menggunakan tuturan dalam kalimat dua kata. Sebagai contoh, anak usia 2 tahun menyatakan fakta dalam tuturan Aing kan [air kran] dan menyatakan penolakan dalam tuturan Emoh iyam [tidak mau mandi] (lihat data S2.B2.2) dan anak usia 3 tahun menyatakan Ini patung dan Beli apel, dan Ada ikan dan Mau rotiDengan bertambahnya perbendaharaan kata yang diperoleh dari lingkungan bahasanya dan karena perkembangan kognitifnya serta fungsi-fungsi lain pada anak, terbentuklah periode penuturan kalimat yang terdiri atas dua kata ini. Dalam menggabungkan dua kata ini anak mengikuti urutan kata yang terdapat pada bahasa orang dewasa. Menurut Bloom (1973) dan Brown (1973), urutan dua kata ini meliputi: (1) agen+aksi, misalnya: bapak datang, adik duduk; (2) aksi+objek, misalnya makan roti, minum susu; (3) aksi+lokasi, misalnya duduk kursi, pergi sekolah; (4) entitas+lokasi, misalnya boneka lemari, susu meja; (5) termilik-pemilik, misalnya boneka adik, tas ibu; (6) entitas+atribut, misalnya balon besar, bola kecil; dan (7) penunjuk+entitas, misalnya itu ikan, ini telepon.

Setelah penguasaan kalimat dua kata, berkembanglah tuturan anak dalam bentuk kalimat yang terdiri atas lebih dari dua kata (more word sentence). Menurut Brown (1973), periode konstruksi kalimat lebih dari dua kata ini 
merupakan hasil penggabungan atau perluasan konstruksi dua kata. Misalnya, agen+aksi (Adik minum) digabungkan dengan aksi+objek (Minum susu) sehingga menjadi struktur agen+aksi+objek (Adik minum susu). Sejalan dengan tahap perkembangan bahasa anak tersebut, anak usia prasekolah menunjukkan penggunaan bentuk-bentuk tuturan untuk menyatakan berbagai maksud dalam kalimat tiga kata, empat kata, dan seterusnya. Sebagai contoh, diujarkannya tuturan Aku pingin tahu. Mbuka ininya lho gimana? Kamu bisa nggambarkan? Nanti ada gentengnya, Aku mau nggambar rumah dulu ah, Ada gentengnya, Kamu nggambar badut bisa?

Fakta penggunaan bahasa tersebut menggambarkan bahwa bentukbentuk tuturan yang dinyatakan anak usia prasekolah sejalan dengan tahap perkembangan bahasa anak sebagaimana telah dirumuskan oleh para pakar sebelumnya (Piaget, 1965; Schaerlaekens 1977; dan Steinberg, 1982). Lebih lanjut, temuan penelitian ini membuktikan bahwa pada tahap tertentu anak usia prasekolah telah mampu mempergunakan bahasa tidak secara egosentris melainkan sudah mempergunakan bahasa untuk berkomunikasi dengan mitra tuturnya. Pada periode ini terjadi konversasi yang sesungguhnya antara anak dengan penutur dewasa.

Dari temuan penelitian ini, hal penting yang perlu diperhatikan dalam tuturan anak bukanlah ucapan-ucapan anak saja melainkan pesan atau maksud yang terkandung di dalam ucapanucapan itu. Menurut Bloom (1970), ucapan anak-anak mempunyai banyak penafsiran. Pada umumnya orang dewasa dapat menafsirkan ucapan tersebut dengan tepat. Meskipun anak hanya mengucapkan satu kata saja, tetapi dapat ditafsirkan sebagai sebuah kalimat lengkap menurut arti dan fungsi dalam komunikasi.
Bentuk-bentuk tuturan yang diujarkan anak usia prasekolah tersebut menjadi bukti empiris bahwa pada tahap ini anak-anak telah mampu menyampaikan maksud komunikasi, meskipun hanya dalam kalimat satu kata. Tuturan dalam kalimat satu kata ini merupakan perwujudan kerja LAD berdasarkan pandangan mentalistik. Berkaitan dengan hal ini dapat dibuktikan bahwa struktur awal bahasa adalah strukturdalam sebelum dikenakan kaidah transformasi. Hal itu sejalan dengan pernyataan Mc. Neil (1970) bahwa struktur awal bahasa anak-anak di seluruh dunia adalah sama meskipun budaya dan bahasa mereka berbeda. Dengan kata lain, struktur-dalam semua bahasa adalah sama, yang berbeda adalah struktur luarnya, setelah melalui rumus-rumus transformasi.

\section{Fungsi Strategi Komunikasi Penutur Anak}

Dalam proses pemerolehan kompetensi pragmatik, strategi komunikasi anak usia prasekolah berfungsi untuk mengatasi problem komunikasi yang dihadapinya ketika anak mengalami kesulitan dalam menyatakan bentuk-bentuk tuturan untuk menyatakan berbagai maksud kepada mitra tuturnya, yaitu bentuk-bentuk tuturan untuk: (1) menyatakan fakta, (2) menyatakan pertanyaan, (3) menyatakan permintaan, (3) menyatakan penolakan, (4) menyatakan tidak suka, (5) menyatakan pendapat, (6) menyatakan alasan, (7) menyatakan nasihat, (8) menyatakan perintah, (9) menyatakan keluhan, (10) menyatakan alasan, (11) menyatakan maaf, (12) menyatakan marah, (13) menyataan larangan, dan (14) menyatakan simpulan. Fungsi penggunaan strategi komunikasi pada anak usia prasekolah tersebut pada tiap jenjang usia menunjukkan adanya perkembangan.

Perkembangan fungsi penggu- 
naan strategi komunikasi sesuai dengan usia anak ini membuktikan adanya pengaruh perbedaan kematangan psikologis dan sosial budaya anak terhadap penggunaan strategi komunikasi dalam pemerolehan kompetensi pragmatiknya. Proses pemerolehan kompetensi pragmatik ber-BI anak usia prasekolah dipengaruhi oleh faktor sosial-budaya masyarakat tutur BJ dan BI serta faktor afektif anak sebagai penutur bahasa di lingkungan keluarga etnik Jawa yang tinggal di perkotaan. Temuan ini berimplikasi pada perlunya penanaman norma budaya sejak dini kepada anak sehingga anak memiliki kepekaan dalam menggunakan bentuk-bentuk kebahasaan yang sesuai dengan konteksnya. Hal ini sejalan dengan pernyataan Ferdman (1990 dalam Nowak-Fabrykowski dan Shkandrij, 2005), pengintegrasian dan pengadaptasian budaya perlu dilakukan untuk membantu anak-anak dalam menggunakan bahasa sesuai dengan norma-norma penggunaannya.

Sebagai penutur dwibahasawan Jawa-Indonesia, orangtua dan pendidik perlu menciptakan kondisi yang dapat mendukung anak untuk mempelajari kapan mereka harus menggunakan BJ dan kapan harus menggunakan BI serta bagaimana cara menggunakannya secara tepat sesuai dengan konteks komunikasi. Pemahaman anak terhadap pengetahuan tersebut akan berdampak pada penggunaan strategi komunikasi yang berdasarkan BJ atau BI. Menurut Fasold (1984:192), pengalihan kode tuturan berkaitan erat dengan nilai-nilai sosial budaya yang mengungkapkan nilai-nilai sosiobudaya masyarakatnya. Penutur dapat melakukan pilihan bahasa yang berbeda-beda sesuai dengan nilai-nilai budaya yang termuat di dalamnya. Dengan demikian, pilihan penggunaan BJ dan BI oleh anak usia prasekolah dapat mendukung proses penguasaan anak terhadap pemaham- an nilai-nilai sosiobudaya yang terkandung dalam kedua bahasa tersebut. Pemahaman nilai-nilai sosiobudaya ini berperan penting dalam performansi berbahasa seseorang. Menurut Hymes (1975), performansi berbahasa seseorang bukan sekedar realisasi dari kemampuan linguistik melainkan mencakup pengetahuan penutur mengenai aspek-aspek sosial budaya di luar bahasa. Sejalan dengan pendangan tersebut, Saville-Troike (1986:2-3) berpendapat bahwa untuk dapat berkomunikasi secara pantas, penutur dipersyaratkan untuk tidak hanya memiliki pengetahuan tentang kaidah komunikasi dan kaidah interaksi tetapi juga kaidah budaya yang melatarinya.

Pengaruh perbedaan kematangan psikologis dan sosial budaya anak terhadap penggunaan strategi komunikasi dalam pemerolehan kompetensi pragmatik anak ini berimplikasi pada perlunya orangtua dan pendidik memperhatikan perkembangan dan kematangan kognisi anak. Pemahaman ini diperlukan agar mereka dapat memperkenalkan bentuk-bentuk tuturan dan penggunaannya secara tepat kepada anak-anak untuk mengembangkan kompetensi pragmatiknya. Dalam proses pemerolehan kompetensi pragmatiknya, anak perlu mendapat dukungan orangtua dan pendidikuntukmemberikankesempatan kepada anak untuk memanfaatkan kreativitas ber-bahasanya dalam praktik menggunakan bahasa secara nyata dalam kehidupan sehari-hari. Hal itu sejalan dengan penyataan Garton dan Pratt (1998:69) bahwa "Chidren must be given the apportunity to develop their spoken language skills in interaction with others". Pernyataan tersebut mempertegas pandangan Vigotsky (1978) dan Bruner (1983) bahwa hanya melalui interaksi sosial anak dapat mengembangkan keterampilanberbahasadanmempelajari cara menggunakan bahasa. 
Sebagai penutur dwibahasawan Jawa-Indonesia, penggunaan strategi komunikasi dalam proses pemerolehan kompetensi pragmatik dipengaruhi oleh faktor sosial-budaya masyarakat tutur BJ dan BI. Proses pemerolehan kompetensi pragmatik tersebut dipengaruhi oleh proses penyerapan budaya BJ dan BI oleh anak pada tiap jenjang usia. Dengan kata lain, keberhasilan anak dalam memperoleh kompetensi pragmatiknya ditentukan oleh keberhasilannya dalam mengakulturasikan dirinya pada bahasa target yang dipelajarinya. Untuk memperoleh gambaran yang lebih mendalam tentang pengaruh faktor sosial budaya dalam proses pemerolehan kompetensi pragmatik tersebut perlu dilakukan penelitian lebih lanjut. Oleh sebab itu, berdasarkan temuan ini direkomendasikan bagi peneliti berikutnya untuk melakukan penelitian dengan fokus kajian tentang pengaruh faktor sosial budaya terhadap pemerolehan kompetensi pragmatik anak usia prasekolah.

\section{PENUTUP}

Strategi komunikasi merupakan cara-cara yang dilakukan anak untuk menyatakan maksud ketika menghadapi kesulitan komunikasi karena keterbatasan kemampuan berbahasanya. Dalam penggunaan berbagai strategi komunikasi anak dapat melatih dan mengembangkan kompetensi pragmatiknya. Pada penutur anak, penggunaan strategi komunikasi pada masing-masing jenjang usia memiliki karakteristik yang berbeda, meskipun terdapat kesamaan-kesamaan. Karakteristik penggunaan strategi komunikasi tersebut tampak pada tipe dan variasi tipe, faktor penyebab, dan fungsi penggunaannya dalam pemerolehan kompetensi pragmatik.

Tipe dan variasi tipe strategi komunikasi yang digunakan penutur anak diklasifikasikan dalam dua kategori, yaitu: (1) strategi penggunaan bentuk nonverbal dan (2) strategi penggunaan bentuk verbal. Strategi penggunaan bentuk nonverbal digunakan anak usia prasekolah secara berbeda-beda sejalan dengan perkembangan usia dan tingkat penguasaan bahasa mereka. Strategi ini digunakan anak dalam empat tipe, yaitu penggunaan isyarat dan gerakan, penggunaan gerakan, penggunaan gambar, dan penggunaan lagu. Strategi penggunaan bentuk verbal oleh anak usia prasekolah merefleksikan upaya anak untuk memanfaatkan bentuk-bentuk tuturan yang telah dikuasainya untuk berkomunikasi. Strategi penggunaan bentuk verbal ini digunakan anak usia prasekolah dalam dua tipe, yaitu (1) strategi penggunaan bentuk tuturan dan (2) strategi penggunaan isi tuturan. Strategi penggunaan bentuk tuturan digunakan anak usia prasekolah dalam tiga variasi tipe, yaitu pengalihan kode tuturan, pemaparan tuturan, dan penciptaan kata kreatif. Strategi pengungkapan isi tuturan digunakan anak dalam tiga variasi tipe, yakni penajaman maksud tuturan, pengalihan topik tuturan, dan pemutusan pesan.

Penggunaan strategi komunikasi penutur anak ini disebabkan oleh adanya berbagai faktor, yaitu tingkat perkembangan usia, tingkat penguasaan bahasa, sumber problema komunikasi, kepribadian pembelajar, tujuan komunikasi, dan situasi belajar. Faktor-faktor penyebab penggunaan strategi komunikasi yang telah dipaparkan tersebut menggambarkan bahwa proses pemerolehan kompetensi pragmatik penutur anak melibatkan faktor internal dan faktor lingkungan bahasanya.

Fungsi penggunaan strategi komunikasi penutur anak adalah untuk mengatasi keterbatasan penguasaan bahasanya dan untuk menjaga kelangsungan komunikasi. Penggunaan berbagai 
tipe dan variasi tipe strategi komunikasi tesebut berfungsi untuk menguasai berbagai bentuk tuturan untuk menyatakan berbagai maksud kepada mitratuturnya, yakni untuk menyatakan fakta, menyatakan pertanyaan, menyatakan permintaan, menyatakan penolakan, menyatakan tidak suka, menyatakan pendapat, menyatakan alasan, menyatakan nasihat, menyatakan perintah, menyatakan keluhan, menyatakan alasan, menyatakan maaf, menyatakan marah, menyataan larangan, dan menyatakan simpulan. Fakta penggunaan bentuk nonverbal dan bentuk verbal oleh anak membuktikan bahwa anak telah mampu mengatasi kendala komunikasi dengan cara yang dimilikinya dengan tepat. Ketepatan penggunaan bentuk verbal ditunjukkan dengan kekomunikatifan penggunaannya yang tampak pada kemudahan mitra tutur untuk memahami maksud tuturan anak.

\section{UCAPAN TERIMA KASIH}

Artikel ini diangkat dari penelitian yang dilaksanakan pada tahun 2009 dengan anggaran Penelitian Hibah Bersaing DPPM DIKTI. Ucapan terima kasih disampaikan kepada Lembaga Penelitian Universitas Islam Malang yang telah memfasilitasi pelaksanaan penelitian ini. Selanjutnya ucapan terima kasih disampaikan kepada dua reviewer anonim yang telah membaca, mengoreksi dan memberi masukan terhadap artikel ini.

\section{DAFTAR PUSTAKA}

Bellugi, U. 2006. Contrasting Profiles of Language Development in Children With William and Down Syndromes. Journal of Developmental Neuropsychology, vol.13, Pg.345). http/www.questia. com. 2006.

Bialystok, E. 1983. Selection and Im- plimentation of Communication Strategies dalam Faerch and Kasper Gabriele (Eds.) Strategies in Interlanguage Communication. London: Longman.

Bialystok, E. 1990. Communication Strategies, A Psychological Analysis of Second Language Use. Oxford: Basil Blackwell Ltd.

Bloom, L. 1970. Language Development. Cambridge, MA: MIT Press.

Blum-Kulka, S. dan E. A. Lavenston. 1983. Universal of Lexical Simplification. Dalam Faerch, C. dan G. Kasper (Eds.), Strategies in Interlanguage Communication. London: Longman.

Clark, E. V. 1983. Meanings and Concepts. Dalam Flavell, J. H. dan E.M. Markam (eds), Handbook of Chil Psychology, vol III: Cognitive Development. New York: John Wiley)

Clark, E. V. dan R.A. Berman. 1987. Type of Linguistic Knowledge: Interpreting and Producing Compound Nouns. Journal of Child Language, 14, 547--67.

Corder, S. P. 1983. Strategies of Communication. Dalam Faerch, $C$ and Kasper G. (Eds.) Strategies in Interlanguage Communication. London: Longman.

Dulay, H., M. Burt, dan S. Krashen. 1982. Language Two. New York: Oxfort University Press.

De-Paiva, B.M.M.D. 2005. The Acquisition of Pragmatic Abilities in A Second Language: Requests in Brazilian Portuguese. Desertasi, Heriot-Watt Uni-versity, Edinburgh, Scotland.

Duranti, A. 2000. Linguistic Anthropology. Cambridge: Cambridge University Press.

Dunduan-Li, 2004. The Pragmatic of Making Requests in the L2 Workplace: A case study of Language Socialization. Canadian 
Modern Language Review Journal, Vol 57, No.1, September 2004.

Ellis, R. 1986. Understanding Second Language Acquisition. Oxford: Oxford University Press.

Ellis, R. 1994. The Study of Second Language Acquisition. Oxford: Oxford University Press.

Foster, S. H. 1990. The Communicative Competence of Young Children. New York: Longman.

Hatch, E. M. 1983. Psycholinguistics: A Second Language Perspective. Rowley: Newbury House Publishers.

Hymes, D. 1975. On Communicative Competence. Philadelphia, P.A.: University of Pennsylvania Press.

Ingram, D. 1971. Transitivity in child languge. Language 47, 888--910.

Keller , J. dan Trixi Rech. 1998. "Towards a Modular Description of the Defisits in Spontaneous Speech in Dementia." Journal of Pragmatics 29, 313-332.

Levinson, S. C. 1992. Pragmatics. Cambridge: University Press.

Mey, Yacob L. 1993. Pragmatics an Introduction. Cambridge, Massachusetts: Blackwell Publisher Ltd.

Mwinyelle, J. B. 2005. "The Acquisition of Pragmatic Compentencein second Language: The Case of Advice in Spanis." Paper Presen-tation The Twelfth Learning Conference on Learning in The Faculty at the University of Granada from Monday $11^{\text {th }}$ to Thursday July 2005.

Nowak-Fabrykowski, $\mathrm{K}$ dan $\mathrm{M}$. Shkandrij. 2005. "The Simbolic Word of Bilingual Children: Digressions on Language Acquisition, Culture and the Process of Thinking. Journal of Intructional Psychology. Vol. 3.
Issue: $4.284-313$.

Oxford, R. L. 1990. Language Learning Strategies: What Every Teachers Should Know. Boston, Mass.: Hainle \& Heinle Publishers.

Piaget, J. 1965. The Language and Thought of the Child. New York: the World Publishing Company.

Saville-Troike, M. 1986. The Ethnography of Communication. New York: Basil Blackwell Ltd.

Scherlaekens, A. M. 1982. The TwoWord Sentence in Child Language Development: A Study Based on Evidence Proded by Dutch-Speaking Triplets. The Hague: Moutan \& Co. N.V., Publisher.

Schiffrin, D. 1994. Approaches to Discourse Analysis. Cambridge: Blackwell Publisher.

Steinberg, D.D. 1982. Psycholinguistics Language Mind and Word. London: Longman.

Tarone, E., Andrrew D. Cohen, dan G. Dumas, 1980. A Closer Look at Some Interlaguage Terminology: A Framework for Communication Strategies. Dalam Faerch, C and Kasper G. (Eds.) Strategies in Interlanguage Communication. London: Longman.

Tarone, E. 1983. Some Thougths on The Nation of Communication Strategy, dalam Faerch, C and Kasper G. (Ed.) Strategies in Interlanguage Communication. London: Longman.

Vigotsky, L. S. 1986. Thought and Language. Cambridge, MA: Harvard University Press.

Van Ek, J. A. 1983. Systems Development in Adult Language Learning in Schools. London: Longman. 


\begin{tabular}{|c|c|c|}
\hline & JUDUL & KARAKTERISTIK PENELITIAN \\
\hline 1 & $\begin{array}{l}\text { The Acquisition of } \\
\text { Pragmatic abilities in } \\
\text { second language: Requests } \\
\text { in Brazilian Portuguese } \\
\text { (De-Paiva, } 2005 \text { dalam } \\
\text { DOCTORAL } \\
\text { WORKSHOP, Vol.17 } \\
\text { No.3E4) }\end{array}$ & $\begin{array}{l}\text { Sasaran penelitian: mengkaji perkembangan } \\
\text { strategi permintaan dalam bahasa Portugis } \\
\text { Brasil sebagai bahasa kedua dan adopsi } \\
\text { metode cross-cultural. } \\
\text { - Metode (1) penelitian ini mengunakan } \\
\text { rancangan cross-sectional dalam penelitian } \\
\text { pemerolehan pragmatik dan (2) } \\
\text { menggunakan teknik analisis data, yaitu } \\
\text { analisis konteks wacana dalam tindak tutur. } \\
\text { Hasil: penelitian ini menunjukkan adanya } \\
\text { keterkaitan aspek eksternal (input bahasa } \\
\text { dan interaksi) dalam pemerolehan } \\
\text { pragmatik. }\end{array}$ \\
\hline 2 & $\begin{array}{l}\text { The Acquisition of } \\
\text { Pragmatic Competence in } \\
\text { Second Language: The } \\
\text { Case of advice in spanish } \\
\text { (Mwinywlle, } 2005 \text { dalam } \\
\text { The Thelfh International } \\
\text { Conference on Learningin } \\
\text { the Faculty of Education } \\
\text { at the University of } \\
\text { Granada 11-14 July 2005) }\end{array}$ & $\begin{array}{l}\text { Metode: (1) penelitian ini menggunakan } \\
\text { subjek pembelajar usia sekolah dan (2) } \\
\text { penelitian ini menggunakan desai } \\
\text { eksperimental dengan pre-test/post-test. } \\
\text { Teori: penelitian ini menggunakan kaidah } \\
\text { sosio-pragmatik dalam pengkajian tidak } \\
\text { tutur, yang meliputi (1) advice head act, (2) } \\
\text { expressions, (3) amount of information, (4) level } \\
\text { of formality, (5) level of directness, dan (6) } \\
\text { politeness. } \\
\text { Hasil: Pembelajar dalam kelompok } \\
\text { eksperimen yang diberi perlakuan dengan } \\
\text { pemberian pembelajaran komponen } \\
\text { sosiopragmatik dan pragmalinguistik } \\
\text { menunjukkan kompetensi pragmatik yang } \\
\text { lebih baik dalam tindak tutur menasehati } \\
\text { daripada pembelajar dalam kolompok } \\
\text { kontrol. }\end{array}$ \\
\hline 3 & $\begin{array}{l}\text { The Pragmatic of Making } \\
\text { Requests in the L2 } \\
\text { Workplace: A case study } \\
\text { of Language Socialization } \\
1 \text { (Dunduan-Li, } 2004 \\
\text { dalam Canadian Modern } \\
\text { Language Review Journal, } \\
\text { Vol } 57, \text { No.1, September } \\
\text { 2004. }\end{array}$ & $\begin{array}{l}\text { - Metode(1) subjek penelitian ini adalah } \\
\text { penutur bahasa dewasa imigran, (2) } \\
\text { penelitian ini menggunakan desain crooss- } \\
\text { sectional dengan pengamatan selama } 5 \text { bulan, } \\
\text { dan (3) fokus kajian ini adalah interlanguage } \\
\text { pragmatic dalam permintaan penutur. } \\
\text { Teori: penelitian ini menggunakan ancangan } \\
\text { teori kombinasi antara interlanguage } \\
\text { pragmatic, etnografi, dan sosialisasi bahasa }\end{array}$ \\
\hline
\end{tabular}




\begin{tabular}{|c|c|c|}
\hline & & $\begin{array}{l}\text { (language socialization) } \\
\text { Hasil: penelitian ini subjek dapat } \\
\text { menggunakan permintaan secara langsung, } \\
\text { yang sebelumnya mereka biasa melakukan } \\
\text { dengan cara mengadopsi ungkapan dan } \\
\text { strategi sosiolinguistik tertentu. }\end{array}$ \\
\hline 4 & $\begin{array}{l}\text { Contrasting Profiles of } \\
\text { Language Development in } \\
\text { Children With William } \\
\text { and Down Syndromes } \\
\text { (Ursula Bellugi, 2006, } \\
\text { Journal Title: } \\
\text { Developmental } \\
\text { Neuropsychology, vol.13, } \\
\text { Pg.345). } \\
\text { http/www.questia.com. } \\
2006 \text { Find articles }\end{array}$ & 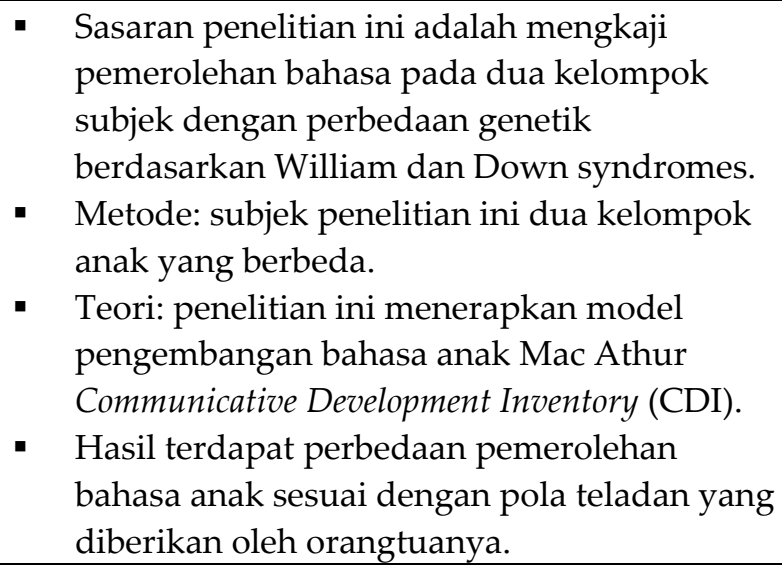 \\
\hline 5 & $\begin{array}{l}\text { The Symbolic Word of the } \\
\text { Bilingual Child: } \\
\text { Digression on Language } \\
\text { Acquisition, Culture, and } \\
\text { the Process of Thinking. } \\
\text { Nowak-Fabrykowski dan } \\
\text { Shkandri, } 2004 \text { dalam } \\
\text { Journal of Instrucional } \\
\text { Psychology, Vol.31, Issu } \\
\text { 4,2004, Pg 284. } \\
\text { http:/www.questia.com. }\end{array}$ & $\begin{array}{l}\text { - Fokus penelitian: eksplorasi hubungan antara } \\
\text { pemerolehan bahasa dan konstruksi dunia } \\
\text { simbolik anak imigran yang dwibahasawan. } \\
\text { - Metode: (1) survai penggunaan bahasa pada } \\
\text { domain pekerjaan, sekolah, pemerintahan, } \\
\text { keagamaan, dan keluarga, (2) studi } \\
\text { dokumentasi, (3) observasi, (4) kajian teori. } \\
\text { - Hasil: penelitian ini menemukan hubungan } \\
\text { antara pemerolehan bahasa dan proses } \\
\text { berpikir yang berkaitan dengan pandangan } \\
\text { dunia simbolik anak dwibahasawan. }\end{array}$ \\
\hline
\end{tabular}

